\title{
Pengaruh Kombinasi Media Lapisan Tanah dan Takaran Cocopeat pada Pertumbuhan Bibit Kakao (Theobroma cacao L.)
}

\section{(Effect of Media Layer of Soil and Cocopeat Combination on Growth of Cocoa Seedling [Theobroma cacao L.])}

\author{
Eko Saputra $^{1)^{*}}$, Rijadi Subiantoro ${ }^{2)}$, Adryade Reshi Gusta ${ }^{2)}$ \\ 1) Program Studi Produksi dan Manajemen Industri Perkebunan Politeknik Negeri Lampung dan ${ }^{2)}$ \\ Jurusan Budidaya Tanaman Perkebunan Politeknik Negeri Lampung, Jl. Soekarno-Hatta No.10 \\ Rajabasa, Bandar Lampung, 35144, Telp.: (0721) 703995, Fax.: (0721) 787309 \\ E-mail: eko.saputra147@yahoo.com
}

\begin{abstract}
Efforts to produce good quality cocoa seedling in quality and quantity, ie the use of planting media containing nutrients needed by plants. Topsoil and cocopeat combination are expected to increase the growth of cocoa seedling. The purpose of this study was to to obtain a good soil layer medium planting on the growth of cocoa seedling, to obtain optimum cocopeat on the growth of cocoa seedling, and to obtain the interaction of soil layer medium planting and cocopeat on the growth of cocoa seedlings. This research was conducted in Politeknik Negeri Lampung's Teaching Farm in January 2017 until June 2017. The experiment was conducted by factorial randomized block design with two factors and each treatment combination was repeated 3 times. The first factor consists of two levels and the second factor consists of four levels. The first factor, namely top soil and sub soil. The second factor is composting cocopeat on planting medium consisting of $0 \%$ cocopeat and 100\% soil, 25\% cocopeat and 75\% soil, 50\% cocopeat and 50\% soil, 75\% cocopeat and 25\% soil. The results showed that the cocopeat 0\%-75\% gave the same effect on the high varieties of seedlings, stem diameter, number of leaves, total dry weight, and dry root weight. In general, top soil and sub soil medium planting did not affected on the growth of cocoa seedling and cocopeat did not affected on the growth of cocoa seedling. There was no interaction between media layer of soil and cocopeat in all observation variables.
\end{abstract}

Keywords: cocopeat, cocoa seedling, sub soil, and top soil

DOI: http://dx.doi.org/10.25181/jaip.v7i1.1051

Diterima: 11 Maret 2019 / Disetujui: 20 April 2019 / Diterbitkan: 12 Mei 2019

\section{PENDAHULUAN}

Kakao (Theobroma cacao L.) di Indonesia merupakan salah satu komoditas andalan perkebunan yang berperan penting dalam perekonomian. Indonesia merupakan negara produsen utama kakao dunia, menempatkan Indonesia sebagai negara produsen terbesar ketiga dunia, negara pesaing utama ekspor kakao Indonesia adalah Pantai Gading dan Ghana. Menurut Statistik Badan Pusat Republik Indonesia (2014).

Budidaya tanaman kakao adalah penyediaan bahan tanam dalam pembibitan, karena dari pembibitan inilah akan didapatkan bahan tanam yang layak untuk ditanam di lapangan yang 
nantinya akan menghasilkan bibit tanaman kakao yang mampu berproduksi secara maksimal. Siregar (2005) menyatakan bahwa pemindahan kecambah ke polibeg dilakukan setelah berumur 21 hari.

Upaya untuk menghasilkan bibit kakao yang baik secara kualitas dan kuantitas, yaitu penggunaan media tanam. Media tanam merupakan komponen utama yang perlu diperhatikan, terutama keberadaan unsur hara yang terdapat pada media tanam tersebut. Media tanam yang digunakan pada umumnya adalah tanah lapisan atas (top soil) yang subur. Lapisan tanah atas (top soil) telah sulit didapatkan, hal itu disebabkan penggunaan yang terus menerus ataupun terkikis akibat erosi. Pemberian kompos dan cocopeat adalah alternatif yang dapat mencegah menurunya kualitas media tanah.

Cocopeat adalah serbuk halus sabut kelapa yang dihasilkan dari proses penghancuran sabut kelapa. Cocopeat dapat menahan kandungan air dan unsur kimia pupuk serta menetralkan kemasaman tanah (Irawan, 2014). Media tanam top soil dan dikombinasikan dengan cocopeat diharapkan dapat meningkatkan pertumbuhan bibit kakao.

\section{METODE PENELITIAN}

Penelitian dilaksanakan di Lahan Percobaan Politeknik Negeri Lampung pada bulan Januari 2017 hingga bulan Juni 2017. Alat dan bahan yang digunakan dalam kegiatan penelitian ini adalah alat tulis, gunting, penggaris, kamera, jangka sorong, pisau cutter, koret, polybag, tali plastik, bambu, kertas label, benih kakao klon ICS 60, tanah lapisan atas (top soil), tanah lapisan bawah (subsoil), dan cocopeat yang telah dihaluskan.

Penelitian ini menggunakan Rancangan Acak Kelompok (RAK) faktorial yang terdiri atas 2 faktor, faktor pertama yaitu media tanam dan faktor kedua yaitu kompos cocopeat dilakukan 3 (tiga) kali ulangan. Faktor pertama yang digunakan adalah top soil $\left(\mathrm{P}_{1}\right)$ dan sub soil $\left(\mathrm{P}_{2}\right)$. Faktor kedua yaitu pemberian kompos cocopeat terdiri dari 4 taraf, control/tanpa cocopeat $\left(\mathrm{K}_{0}\right)$, cocopeat $25 \%$ dari volume polybag $\left(\mathrm{K}_{1}\right)$, cocopeat $50 \%$ dari volume polybag $\left(\mathrm{K}_{2}\right)$, dan cocopeat $75 \%$ dari volume polybag $\left(\mathrm{K}_{3}\right)$. Penelitian diulang 3 kali dengan 8 kombinasi perlakuan sehingga terdapat 24 satuan percobaan. Pengamatan dilaksanakan 4 (empat) kali selama penelitian ini berlangsung. Variabel yang diamati yaitu tinggi tanaman, diameter batang, jumlah daun, bobot kering brangkasan, bobot kering akar, dan kadar air tanah. Pengamatan pada variabel bobot kering brangkasan, bobot kering akar, dan kadar air tanah dilakukan pada akhir penelitian.

\section{HASIL DAN PEMBAHASAN}

\section{Analisis Bahan Penelitian}

Bahan penelitian terdiri atas top soil, sub soil dan kompos berbahan baku cocopeat. Kompos berbahan baku cocopeat dihasilkan dari pabrik pengolahan sebutret (serabut kelapa 
berkaret) Politeknik Negeri Lampung. Top soil diperoleh dari lahan Taman Sari Desa Hajimena Kabupaten Lampung Selatan dan sub soil diperoleh dari lahan Unit Pembibitan Kelapa Sawit Politeknik Negeri Lampung.

Tabel 1. Hasil analisis top soil, sub soil, dan kompos cocopeat

\begin{tabular}{lccc}
\hline \multicolumn{1}{c}{ Parameter } & Top soil & Sub soil & Cocopeat \\
\hline N total (\%) & 0,24 & 0,21 & 1,18 \\
P tersedia (ppm) & 11,4 & 0,93 & 0,99 \\
K total (me) & 1,56 & 1,61 & 1,55 \\
C-organik $(\%)$ & 2,90 & 0,28 & 7,38 \\
pH & 7,5 & 5,83 & 6,83 \\
C/N ratio & & & 6,25 \\
\hline
\end{tabular}

Keterangan: Laboratorium Analisis Politeknik Negeri Lampung

Tabel 2 menunjukkan bahwa perlakuan media tanam baik top soil maupun sub soil menunjukkan tidak berpengaruh pada tinggi bibit, diameter batang, jumlah daun, bobot kering berangkasan, dan bobot kering akar. Perlakuan dosis cocopeat juga tidak berbeda nyata terhadap tinggi bibit, jumlah daun, bobot kering brangkasan, dan bobot kering akar. Perlakuan media tanam dan dosis cocopeat tidak menunjukkan interaksi pada semua variabel pengamatan.

Tabel 2. Hasil pengamatan tinggi bibit $(\mathrm{cm})$, diameter batang $(\mathrm{mm})$, jumlah daun (helai) dan bobot kering brangkasan (g) pada perlakuan dosis cocopeat dan media top soil dan sub soil

\begin{tabular}{clccccc}
\hline \multirow{2}{*}{ Perlakuan } & \multicolumn{5}{c}{ Variabel Pengamatan } \\
\cline { 3 - 7 } & & $\begin{array}{c}\text { Tinggi } \\
\text { Tanman }\end{array}$ & $\begin{array}{c}\text { Diameter } \\
\text { Batang }\end{array}$ & $\begin{array}{c}\text { Jumlah } \\
\text { Daun }\end{array}$ & BKB & \multirow{2}{*}{ BKA } \\
\hline Media lapisan & Top soil & $32,61 \mathrm{a}$ & $0,74 \mathrm{a}$ & $13,17 \mathrm{a}$ & $26,99 \mathrm{a}$ & $8,16 \mathrm{a}$ \\
tanah & Sub soil & $31,51 \mathrm{a}$ & $0,71 \mathrm{a}$ & $13,83 \mathrm{a}$ & $25,48 \mathrm{a}$ & $7,31 \mathrm{a}$ \\
\hline \multirow{4}{*}{ Cocopeat } & Cocopeat $0 \%$ & $25,47 \mathrm{a}$ & $0,57 \mathrm{a}$ & $11,13 \mathrm{a}$ & $20,73 \mathrm{a}$ & $6,05 \mathrm{a}$ \\
& Cocopeat $25 \%$ & $24,97 \mathrm{a}$ & $0,55 \mathrm{a}$ & $10,13 \mathrm{a}$ & $20,13 \mathrm{a}$ & $5,80 \mathrm{a}$ \\
& Cocopeat $50 \%$ & $22,66 \mathrm{a}$ & $0,54 \mathrm{a}$ & $9,13 \mathrm{a}$ & $18,74 \mathrm{a}$ & $5,67 \mathrm{a}$ \\
& Cocopeat 75\% & $23,09 \mathrm{a}$ & $0,52 \mathrm{a}$ & $10,13 \mathrm{a}$ & $19,10 \mathrm{a}$ & $5,68 \mathrm{a}$ \\
\hline & Interaksi & $(-)$ & $(-)$ & $(-)$ & $(-)$ & $(-)$ \\
\hline
\end{tabular}

Keterangan: Nilai rata-rata yang diikuti oleh huruf yang sama pada kolom yang sama menunjukkan tidak berbeda nyata dengan uji BNT pada taraf 5\%.

Media tanam merupakan komponen utama yang diperlukan untuk menigkatkan pertumbuhan bibit kakao karna media tanam mengandung unsur hara yang dibutuhkan oleh tanaman. Hal ini sesuai dengan pernyataan Marsono (2002), yang menyatakan bahwa peranan utama dari nitrogen adalah untuk merangsang pertumbuhan secara keseluruhan bagian tanaman khususnya batang, cabang, dan daun tanaman. Nitrogen merupakan penyusun utama protein dan sebagai bagian dari klorofil yang mempunyai peranan penting pada proses fotosintesis (Tisdale et al., 2003). 
Tabel 2 memperlihatkan bahwa pertumbuhan bibit kakao memiliki rata-rata nilai yang hampir sama. Perlakuan cocopeat $0 \%$ menujukan nilai sebesar $25,47 \mathrm{~cm}$, memberikan pengaruh yang sama dengan perlakuan lainnya. Hal ini diduga karena cocopeat dari hasil analisis pendahuluan didapatkan kandungan unsur hara yang sangat rendah sehingga kebutuhan nutrisi tanaman tidak tercukupi. Pertumbuhan tanaman kakao dipengaruhi oleh unsur hara yang terdapat dalam media yang digunakan (Wuryaningsih, 2003).

Nilai rerata diameter batang dengan perlakuan top soil sebesar $0,74 \mathrm{~mm}$, memberikan pengaruh yang sama dengan perlakuan sub soil dengan nilai $0,71 \mathrm{~mm}$. Hal ini diduga bahwa tanah top soil memiliki unsur hara yang di butuhkan oleh tanaman. Jumin (2011) menyatakan bahwa batang merupakan daerah akumulasi pertumbuhan tanaman khususnya tanaman muda, dengan adanya unsur hara dapat mendorong laju fotosintesis dalam menghasilkan fotosintat, sehingga membantu dalam pembentukan lilit batang.

Pada perlakuan cocopeat dapat dilihat nilai rerata diameter bantang berkisar antara 0,520,57 mm. Pemberian cocopeat $0 \%$ sampai dengan $75 \%$ memberikan pengaruh yang sama terhadap variabel diameter batang. Hal ini diduga karena dari hasil analisis cocopeat memiliki unsur $\mathrm{K}$ yang rendah, kebutuhan nutrisi pada tanaman yang tidak tercukupi sehingga pertumbuhan tanaman terhambat, Pembesaran diameter batang dipengaruhi oleh ketersediaan unsur $\mathrm{K}$ dalam tanah. Menurut Leiwakabessy (2003) unsur K sangat berperan dalam meningkatkan diameter batang tanaman, khususnya dalam peranannya sebagai jaringan yang menghubungkan antara akar dan daun, kekurangan unsur $\mathrm{K}$ dapat menghambat proses pembesaran lingkar batang.

Untuk variabel jumlah daun (Tabel 2), perlakuan media top soil dan sub soil menunjukan nilai yang sama yaitu 13 helai. Hal ini disebabkan karena tanaman kakao tumbuh dengan pesat dan membutuhkan unsur hara terutama $\mathrm{N}$, sehingga dengan pemberian media top soil dapat meningkatkan ketersediaan unsur $\mathrm{N}$ tersebut. Seperti dikemukakan oleh Lakitan (2000) bahwa unsur hara yang paling berpengaruh terhadap pertumbuhan dan perkembangan daun adalah unsur $\mathrm{N}$. Kadar unsur $\mathrm{N}$ yang banyak umumnya menghasilkan daun yang lebih banyak dan lebih besar.

Pada perlakuaan cocopeat $0 \%$ memiliki nilai sebesar 11 helai, memberikan pengaruh yang sama dengan perlakuan yang lain. Sementara untuk perlakuan cocopeat 50\% memiliki nilai sebesar 9 helai. Pemberian cocopeat $0 \%$ sampai $75 \%$ menunjukan hasil yang tidak berbeda nyata. Hal ini diduga karena kompos sabut kelapa dari hasil analisis pendahuluan didapatkan kandungan unsur hara yang sangat rendah sehingga kebutuhan nutrisi tanaman tidak tercukupi. Kandungan kalium dalam kompos juga sangat berperan dalam meningkatkan total luas daun, berat basah dan berat kering bibit dan magnesium dalam tanah dapat membantu dalam pembentukan daun (Tambunan, 2009).

Sedangkan untuk bobot kering berangkasan, baik media top soil maupun sub soil (Tabel 2), memberikan pengaruh yang sama yaitu 26,99 g yakni pada media top soil, dengan bobot kering berangkasan pada media sub soil yaitu 25,48 g. Tanah top soil memiliki kandungan unsur hara 
lengkap yang dibutuhkan oleh tanaman. Hasil penelitian Gusta et al. (2014) menunjukkan bahwa top soil sangat berpengaruh dalam mengoptimalkan pertumbuhan bibit, kesuburan tanah lapisan ini sulit tergantikan.

Pada perlakuan cocopeat $0 \%$ memberikan pengaruh yang sama pada perlakuan cocopeat $25 \%$ sampai $75 \%$. Hal ini diduga karena pemberian kompos cocopeat yang berlebih tidak dapat meningkatkan pertumbuhan tanaman dan meningkatkan berat kering berangkasan. Jumin (2002) menyatakan bahwa tanaman dapat tumbuh dan berkembang dengan optimal jika tanaman mendapatkan unsur hara dalam jumlah yang tepat.

Selanjutnya dari Tabel 2, dapat dilihat nilai rerataan bobot kering akar dengan perlakuan top soil sebesar 8,16 g dan sub soil dengan nilai 7,31 g. Namun dari hasil kedua media tersebut menunjukan hasil yang tidak berbeda nya. Diketahui bahwa tanah top soil memiliki unsur hara yang dibutuhkan oleh tanaman dan memiliki bahan organik yang tinggi. Bahan organik akan memperbaiki sifat biologi tanah sehingga tercipta lingkungan yang lebih baik bagi perakaran tanaman sehingga akar dapat menyerap unsur hara yang lebih banyak (Pangaribuan dan Pujisiswanto, 2008).

Pada perlakuan cocopeat dapat dilihat nilai rerata bobot kering akar berkisar antara 5,67$6,05 \mathrm{~g}$. Untuk perlakuan cocopeat $50 \%$ menunjukan nilai sebesar $5,67 \mathrm{~g}$, nilai ini paling terkecil dibandingkan perlakuan yang lain. Sementara untuk perlakuan cocopeat $0 \%$ memiliki nilai $6,05 \mathrm{~g}$ lebih besar dari perlakuan cocopeat $25 \%, 50 \%$ dan $75 \%$. Namun pemberian cocopeat $0 \%$ sampai $75 \%$ menunjukan hasil yang tidak berbeda nyata. Hal ini diduga cocopeat dapat mempercepat pemunculan akar dan memperluas penyebaran akar.

\section{Kadar air pada lapisan tanah (\%)}

Pemberian kompos cocopeat pada media tanam bibit kakao berpengaruh terhadap kadar air tanah pada umur 16 minggu setelah tanam (Tabel 3). Pemberian media top soil dan sub soil tidak memberikan pengaruh terhadap kadar air tanah pada umur 16 minggu setelah tanam, sedangkan interaksi keduanya menunjukkan hasil yang berbeda nyata.

Tabel 3. Rata-rata kadar air pada lapisan tanah

\begin{tabular}{lll}
\hline \multicolumn{2}{c}{ Perlakuan } & Rerata kadar air (\%) \\
\hline Media lapisan & Top Soil & $59,62 \mathrm{a}$ \\
tanah & Sub Soil & $65,22 \mathrm{a}$ \\
\hline Cocopeat & Cocopeat $25 \%$ & $30,89 \mathrm{~b}$ \\
& Cocopeat $50 \%$ & $54,34 \mathrm{c}$ \\
& Cocopeat $75 \%$ & $82,77 \mathrm{~d}$ \\
\hline
\end{tabular}

Keterangan: Angka-angka yang diikuti huruf yang berbeda menunjukan antara perlakuan berbeda nyata pada Uji BNT taraf kepercayaan 95\% 
Pemberian cocopeat berpengaruh terhadap kadar air tanah. Semakin tinggi kombinasi cocopeat yang diberikan semakin tinggi kadar air. Hal ini diduga karena media cocopeat pada dasarnya memiliki kemampuan mengikat dan menyimpan air yang sangat kuat. Serbuk sabut kelapa (cocopeat) merupakan media yang memiliki kapasitas menahan air cukup tinggi. Media cocopeat memiliki pori mikro yang mampu menghambat gerakan air lebih besar sehingga menyebabkan ketersediaan air lebih tinggi. Hal ini sesuai dengan pendapat Hanafiah (2007) yang menyatakan bahwa kadar air tanah dipengaruhi oleh kadar bahan organik tanah, makin tinggi bahan organik tanah akan makin tinggi kadar air. Media tanam cocopeat sanggup menahan air hingga $73 \%$.

Pertumbuhan tinggi, diameter batang, dan jumlah daun bibit akibat perlakuan dosis cocopeat dan media lapisan tanah

Untuk mengetahui pertambahan petumbuhan tinggi bibit tanaman kakao 16 MST dapat dilihat pada Gambar 1.

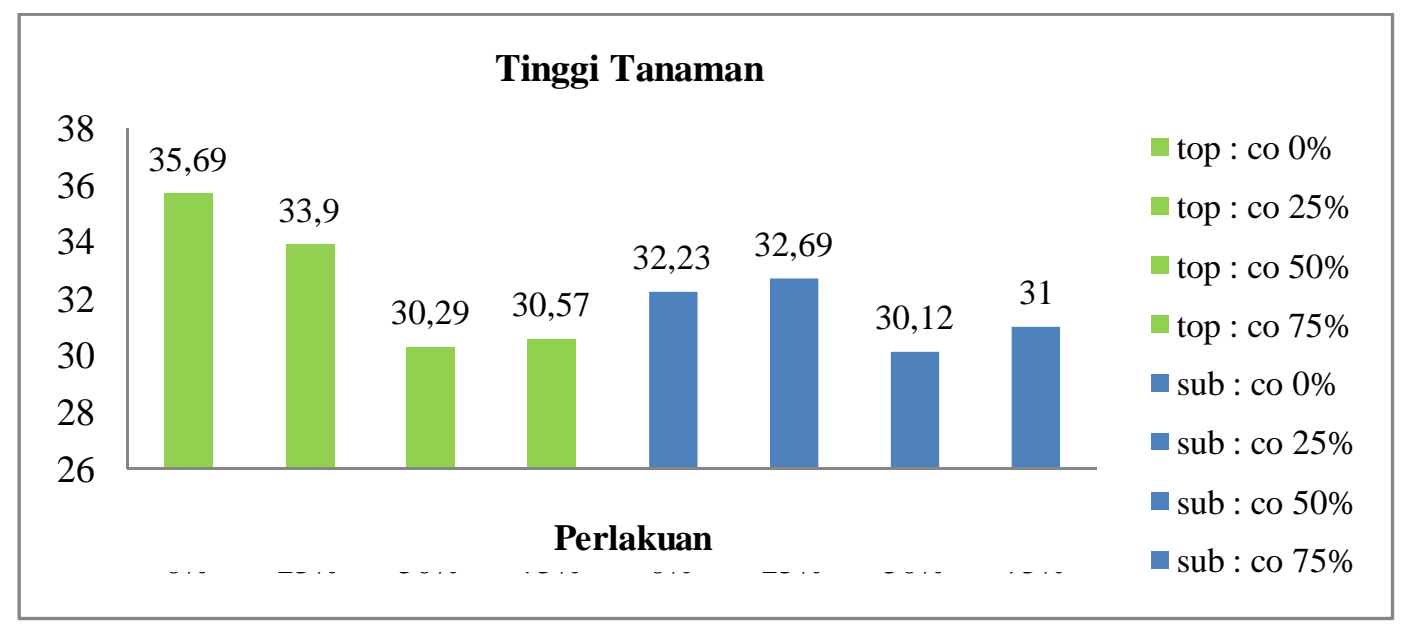

Gambar 1. Pertambahan pertumbuhan tinggi bibit tanaman kakao pada media lapisan tanah

Dari Gambar 1 dapat dilihat bahwa pertambahan pertumbuhan tinggi tanaman baik media top soil, sub soil maupun cocopeat memeberikan pengaruh yang sama. Hal ini diduga karena unsur hara yang dibutuhkan tanaman tidak cukup tersedia. Menurut Sutejo (2002), kekurangan salah satu atau beberapa unsur hara akan menyebabkan pertumbuhan tanaman tidak sebagaimana mestinya. Apabila unsur hara kurang dari kebutuhan yang optimal maka pertumbuhan tidak optimal. Selanjutnya pada zona kekurangan unsur hara laju pertumbuhan tanaman akan lambat (Lakitan 2000).

Untuk mengetahui pertambahan perkembangan diameter batang tanaman kakao 16 MST dapat dilihat pada Gambar 2. 


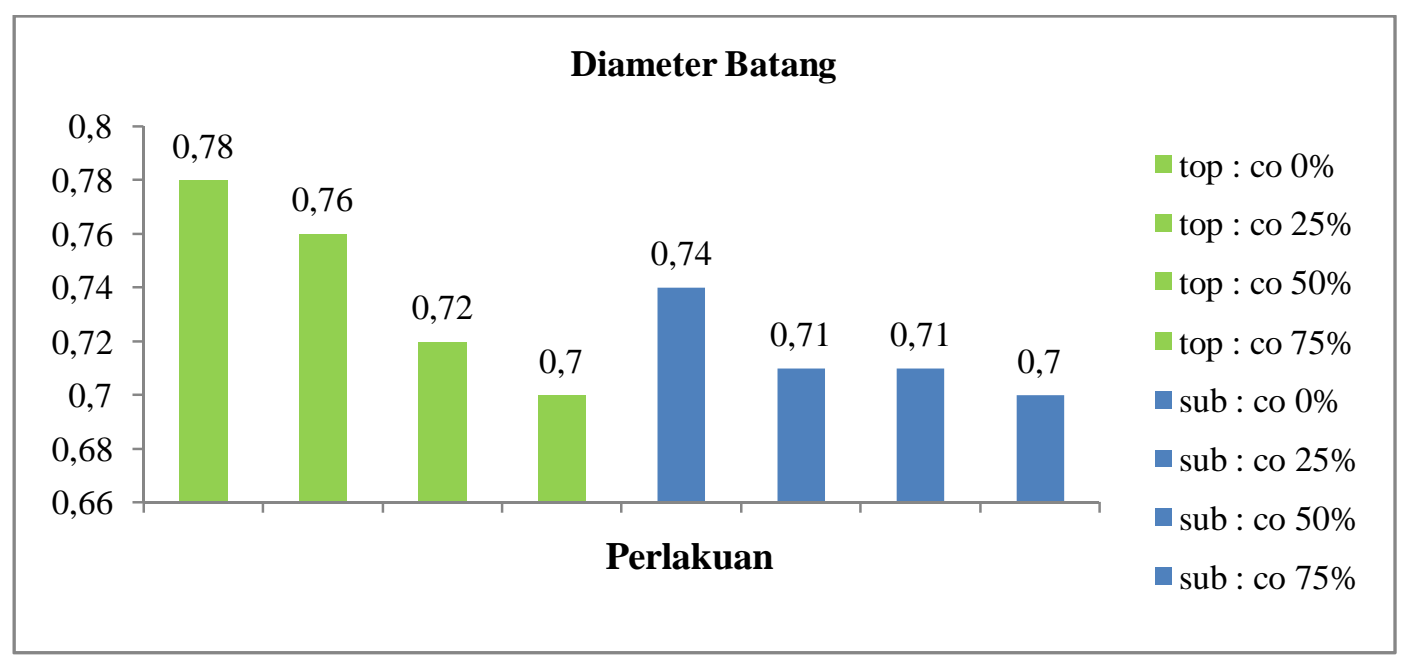

Gambar 2. Pertambahan perkembangan diameter batang tanaman kakao pada lapisan tanah

Pada Gambar 2 dapat dilihat bahwa pertambahan perkembangan diameter batang baik media top soil, sub soil maupun cocopeat memeberikan pengaruh yang sama. Hal ini diduga karena kandungan $\mathrm{K}$ sedikit tersedia sehingga batang kurang berkembang dengan baik, sesuai pernyataan Hakim (2004) unsur K berfungsi menguatkan vigor tanaman yang dapat mempengaruhi besar lingkaran batang. Proses pembesaran diameter batang tidak terlepas dari peranan unsur hara dan hasil fotosintesis, keduanya saling berkaitan.

Untuk mengetahui pertambahan pertumbuhan jumlah daun bibit tanaman kakao 16 MST dapat dilihat pada Gambar 3.

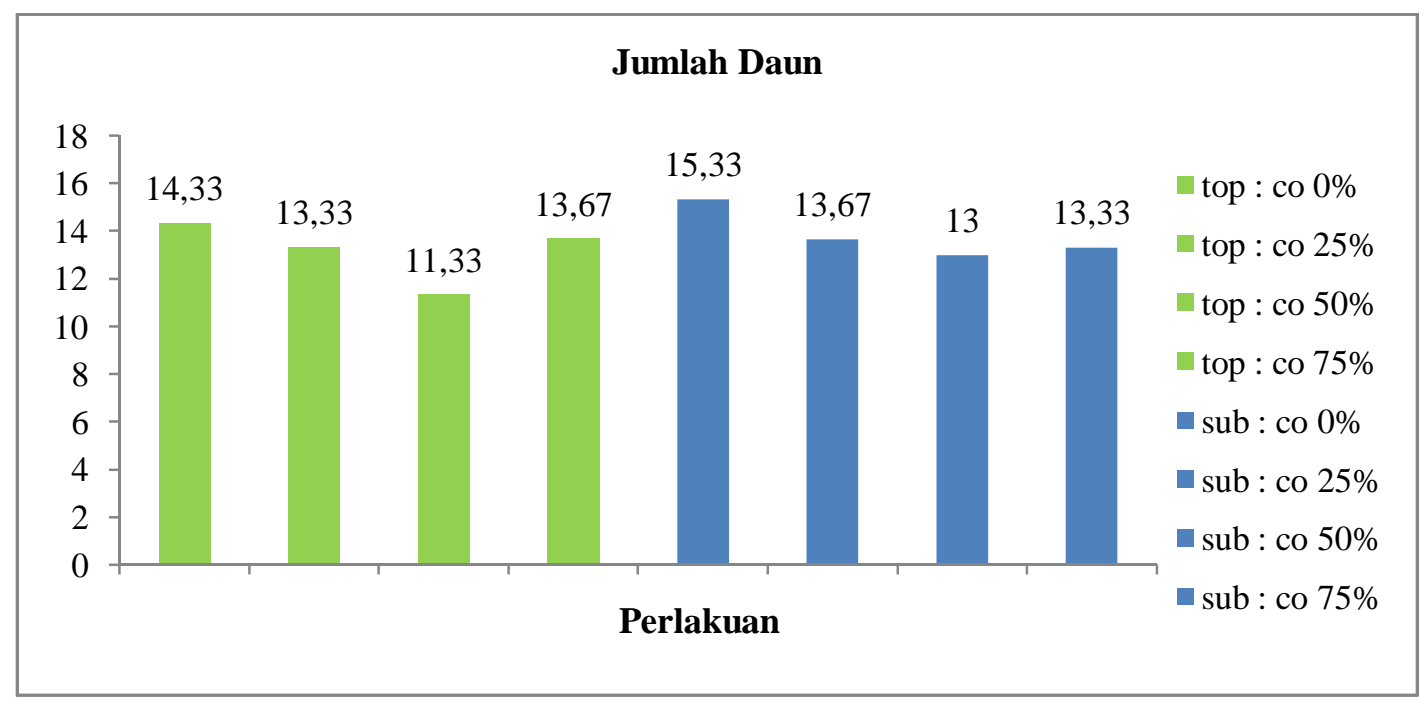

Gambar 3. Pertambahan pertumbuhan jumlah daun bibit kakao pada media lapisan tanah 
Pertambahan jumlah daun baik media top soil, sub soil maupun cocopeat memeberikan pengaruh yang sama. Hal ini diduga pada unsur hara yang terkandung didalam cocopeat tidak terserap optimal oleh tanaman. Menurut Hakim (2004), pembentukan dausn oleh tanaman sangat dipengaruhi oleh ketersediaan unsur hara nitrogen dan fosfor pada tanah dan yang tersedia bagi tanaman. Hasil analisis ragam pertumbuhan tinggi, diameter batang, dan jumlah daun bibit kakao tidak menunjukkan adanya pengaruh nyata dari pemberian dosis cocopeat dan media lapisan tanah.

\section{KESIMPULAN}

Dari hasil penelitian yang telah dilakukan dapat disimpulkan bahwa media top soil dan sub soil memberikan pengaruh yang sama dalam semua variabel pengamatan tinggi tanaman, diameter batang, jumlah daun, bobot kering akar dan bobot kering berangkasan. Takaran cocopeat memberikan pengaruh yang sama dalam semua variabel pengamatan tinggi tanaman, diameter batang, jumlah daun, bobot kering akar dan bobot kering berangkasan. Tidak terdapat interaksi antara media top soil, sub soil dan dosis cocopeat disetiap variable pengamatan.

\section{DAFTAR PUSTAKA}

Gusta, A. R., Kusumastuti, A., \& Parapasan, Y. (2017). Pemanfaatan Kompos Kiambang dan Sabut Kelapa Sawit sebagai Media Tanam Alternatif pada Prenursery Kelapa Sawit (Elaeis guineensis Jacq.). Jurnal Penelitian Pertanian Terapan, 15(2).

Hakim, N., Nyakpa, M. Y., Lubis, A. M., Nugroho, S. G., Saul, M. R., Diha, M. A., ... \& Bailey, H. H. (1986). Dasar-dasar ilmu tanah. Universitas Lampung. Lampung, 488.

Hanafiah, K. A. (2005). Dasar-dasar ilmu tanah. PT RajaGrafindo Persada.

Irawan, A., \& Hidayah, H. N. (2014). Kesesuaian penggunaan cocopeat sebagai media sapih pada politube dalam pembibitan cempaka (Magnolia elegans (Blume). H. Keng). Jurnal Wasian, $1(2), 73-76$.

Jumin, H. B. (2002). Dasar-Dasar Agronomi. Jakarta: Rajawali Press.

Lakitan, B. (2000). Dasar-dasar Fisiologi Tumbuhan. Jakarta: PT RajaGrafindo Persada.

Marsono, P. L. (2002). Petunjuk Penggunaan Pupuk. Jakarta: Penebar Swadaya.

Leiwakabessy, F. M. (1998). Ilmu Kesuburan Tanah dan Penuntun Praktikum. Departemen Ilmu Tanah. IPB. Bogor.

Pangaribuan, D., \& Pujisiswanto, H. (2008, November). Pemanfaatan kompos jerami untuk meningkatkan produksi dan kualitas buah tomat. In Prosiding Seminar nasional Sains dan Teknologi II.

Siregar, T. H., Riyadi, S., \& Nuraeni, L. (2005). Pembudidayaan, Pengolahan dan Pemasaran Cokelat. Jakarta: Penebar Swadaya. 
Statistik, B. P. (2014). Produksi perkebunan menurut provinsi dan jenis tanaman, Indonesia 2012 2015 [Internet].[diunduh 2015 Mar 20]. Tersedia dari: https://www. bps. go. id/linkTableDinamis/view/id/839.

Sutedjo, M. M., \& Kartasapoetra, A. G. (2002). Pengantar Ilmu Tanah. Jakarta: Rineka Cipta.

Tambunan, E. R. (2009). Respon Pertumbuhan Bibit Kakao (Theobroma Cacao L.) Pada Media Tumbuh Sub Soil Dengan Aplikasi Kompos Limbah Pertanian Dan Pupuk Anorganik (Master's thesis).

Tisdale, S. L., Nelson, W. L., Beaton, J. D., \& Havin, J. L. (2003). Soil fertility and fertilizer. published by person education (Singapore) pvt. Ltd. New Delhi. India.

Wuryaningsih, S., Muharram, A., \& Rusyadi, I. (2003). Tanggapan tiga kultivar mawar terhadap media tumbuh tanpa tanah. Jurnal Hortikultura, 13(1), 28-40. 